\title{
A Tipi Kişilik Özelliğinin Kariyerizm Eğilimi Üzerine Etkisinde Ahlaki Çözülme Eğiliminin Aracı Rolü
}

\author{
Ahmet Tuncay ERDEM*
}

ÖZ

Bu çalışmanın temel amacı örgütler açısından sapkın ve yıkıcı davranış biçimleri olarak görülen kariyerizm eğilimi ve ahlaki çözülme eğilimlerinin A tipi kişilik özelliği kapsamında etkilerinin analiz edilmesidir. Bu doğrultuda sosyal bilişsel teori ve kontrol odağ1 ilkesi teorileri kapsamında kariyerizm eğiliminin birey bazında öncüllerini belirlemek amaçlanmaktadır. Araştırmada kariyerizm eğilimi kavramının A tipi kişilik özelliği ve ahlaki çözülme eğilimi kavramlarıyla etkileşimi ele alınmaktadır. Araştırma kapsamında önce konular hakkında kuramsal ve kavramsal çerçeve oluşturulmuş daha sonra özel bir banka çalışanlarına yönelik uygulama yapılmışıtır. Bu çerçevede araştırma örneklemini Konya’da faaliyet gösteren özel bir bankanın çalışanları oluşturmaktadır $(\mathrm{n}=360)$. Araştırma örnekleminden soru formu aracilığılla veriler elde edilerek bu veriler AMOS ve SPSS programları kullanılarak analiz edilmiştir. Analiz kapsamında doğrulayıcı faktör analizi, korelasyon analizi ve yapısal eşitlik modeli analizleri uygulanmıştır. Araştırma bulgularına göre A tipi kişilik özelliğinin kariyerizm eğilimi üzerinde pozitif yönlü anlamlı bir etkisinin olduğu belirlenmiștir. Diğer yandan A tipi kișilik özelliğinin ahlaki çözülme eğilimi üzerinde anlamlı bir etkisinin bulunmadı̆̆ı belirlenmiştir. Bununla birlikte kariyerizm eğiliminin ahlaki çözülme eğilimini pozitif yönlü anlamlı olarak etkilediği belirlenmiştir. Araştırmanın son bulgusu olan A tipi kişilik özelliğinin kariyerizm eğilimine etkisinde ahlaki çözülmenin aracı etkisi tespit edilememiştir. Araştırma bulgularına göre ahlaki çözülme eğiliminin kariyerizm eğilimini güçlendirdiği, A tipi kişilik özelliğinin de kariyerizm eğilimini arttırdığı belirlenmiștir.
\end{abstract}

Anahtar Kelimeler: A tipi kişilik özelliği, kariyerizm, ahlaki çözülme eğilimi.

\section{The Effect of Type A Personality Traits on Careerism: Mediating Effects of Moral Disengagement}

\begin{abstract}
This study's main purpose is to analyze the effects of careerism tendency and moral disintegration tendencies, which are seen as deviant and destructive forms of behavior for organizations within the context of Type A personality. Accordingly, it is aimed to determine the individual premises of the careerism trend within the scope of the theories of social cognitive theory and locus of control theory. The research deals with careerism tendency with the Type A personality trait and moral resolution tendency concepts. Within the research scope, a theoretical and conceptual framework has been formed on the subjects, and then an application has been made for a private bank employee. In this context, the sample consists of employees from a private bank operating in Konya $(\mathrm{n}=360)$. Data have been obtained from the research sample through the questionnaire, and these data have been using AMOS and SPSS programs. Confirmatory factor analysis, correlation analysis, and structural equation model analyses have been applied within the analysis scope. According to the research findings, it was determined that Type a personality trait positively and significantly affects career tendency. On the other hand, it has been determined that type A personality trait does not significantly affect moral resolution. However, it has been determined that the tendency of careerism positively affects the moral resolution tendency. In the relationship between the Type A personality trait, which is the last finding of the research, and the tendency to careerism, moral resolution's mediating effect has not been determined. According to the research findings, it was determined that the moral dissolution tendency strengthens the careerism tendency, and the Type A personality trait increases the tendency towards careerism.
\end{abstract}

Keywords: Type A personality trait, careerism, moral disengagement.

\section{Giriş}

Taklit edilmesi mümkün olmayan örgüt kaynakları olarak bilinen insan kaynakları, örgütlerin rakiplerine karşı rekabet edebilmelerinde önemli aktörler arasında görülmekle birlikte bu kaynakların en verimli şekilde kullanılması gerekliliği açıktır. Örgütlerin sahip oldukları insan kaynaklarını en etkin ve verimli bir biçimde yönetmeleriyle rakiplerine karşı rekabet avantajı elde edecekleri ve kâr elde ederek sürdürebilirliklerini devam ettirebilecekleri söylenebilir. Bu kapsamda örgütleri başarıya ulaştıracak en önemli aracın çalısanlar olduğu bilinmektedir. Çalışanların yetenek ve bilgi noktasında kendilerini geliştirebilecekleri imkânlar sağlanması ve kariyer geliştirme açısından desteklenmesi gerekliliği örgütler açısından önemlidir.

\footnotetext{
* Dr. Öğr. Üyesi, Bolu Abant İzzet Baysal Üniversitesi, ahmeterdem@ibu.edu.tr Makalenin Gönderim Tarihi: 11.06.2020; Makalenin Kabul Tarihi: 17.02.2021
} 
Örgütlerin rakiplerine karşı en etkili rekabet araçlarından biri olan insan gücünün örgüt lehine en iyi ve verimli biçimde kullanılması gerekmektedir. Bu çerçevede her insanın ayırı bir dünyaya benzetildiği günümüzde insanlar ayrı bir değer olarak düşünülmekle birlikte insan çeşitliliğinin fazla olduğu da bilinmektedir. Bu kapsamda insan çeşitliliği kişilik çeşitliliğine de neden olmaktadır (Polatc1 vd., 2020, s.13).

Kişilik, bireylerin doğuştan sahip oldukları ve hayatları boyunca kazanarak şekillendirdikleri ve bireyleri diğer insanlardan ayıran kavram olarak tanımlanmaktadır. Diğer yandan kişilik bireylerin karşılaştıkları farklı durumlarda sergiledikleri davranışları açıllayan, kişiler arasındaki motivasyonel, duygusal, tecrübeye dayalı ve sürekliliği içerisinde barındıran etkileşim tarzı olarak da nitelendirilmektedir (McCrae \& Costa Jr, 1989; Doğan, 2012, s.57; Hatipoğlu \& Akduman, 2019). Ayrıca örgütte çalısan bireylerin kişilik özellikleri gereği daha fazla menfaat sağlama gereksinimi hissetmeleri nedeniyle kariyer hedeflerinde sürekli dikey yönde gelişimi arzu ettikleri de bilinmektedir. $\mathrm{Bu}$ çerçevede kariyer yükselmesinin, çalışanların motivasyonu noktasında olumlu katkılarının olduğu düşünülmektedir. Bu görüşü destekler nitelikte Chay ve Aryee (1999, s.615-616)'e göre sürekli artmakta olan küresel rekabet ve çalışma şartlarındaki değişim; örgütler ve çalışanlar açısından kariyer kavramının ilgi görmesine sebep olmaktadır. Kariyer kavramının bu kadar önem kazanmasıyla birlikte çalışanlar örgütte kariyer hedeflerini belirlemeye başlamışlardır. Bu kapsamda kariyer hedefi, çalışanların gelecekte yer almak istedikleri kariyer seviyelerini belirlemeleri ve bu hedefe yönelik çaba sarf etmeleri açısından önemlidir (Austin \& Vancouver, 1996; Dijksterhuis ve Aarts, 2010).

Örgütte çalışanların kariyer hedefleri belirlemelerinde en önemli etkenin bu kişilerin sahip oldukları kişilik özellikleri olduğu bilinir. Bu kapsamda çalışanların kişilik özelliklerinin belirlenmesi örgütler açısından önem arz etmektedir. Bu araştırma kapsamında ele alınan ve alan yazında "A tipi Kişilik Özelliği” olarak tanımlanan kişilik özelliğine sahip bireylerin; aşırı rekabetçi, işkoliklik düzeyinde kendilerini işlerine adamış kişiler olmalarıyla birlikte bu kişilerin zamana duyarlı, saldırgan, sabırsız ve mümkün olduğu kadar işlerinde başarılı olmayı arzulayan kişiler oldukları belirtilmektedir (Moorhead \& Griffin, 1992, s.462463). Bu çerçevede A tipi kişilik özelliğine sahip bireylerin sabırsız olmaları sebebiyle kariyer hedeflerine diğer çalışanlardan daha hızlı ulaşmak isteyecekleri düşüncesi araştırmanın temel konusunu oluşturmaktadır. Bu noktada kariyerizm kavramı daha da önem kazanmaktadır. Kariyerizme göre çalışanlar, kariyer ilerlemelerini performansa dayalı olarak gerçekleştirmek yerine daha farklı faktörlerle gerçekleştirme eğiliminde olmaktadırlar (Feldman \& Weitz, 1991; Ağırbaş, 2019, s.1).

Alan yazında kişilik ile kariyerizm arasındaki doğrudan ilişkinin ele alındığı çalışmaların oldukça kısıtlı olduğu görülmektedir (Ağırbaş, 2019, s. 2). Bu kapsamda çalışanların kariyerizm eğilimleri ile A tipi kişilik özellikleri kapsamında ahlaki çözülme etkileşimlerini belirlemek amacıyla yapılan bu araştırmayla alan yazına katkı sağlanacağı düşünülmektedir. Araştırma kapsamında kariyerizm kavramının A tipi kişilik özelliği ile ahlaki çözülme eğilimleri arasındaki ilişkiler sosyal bilişsel teori ve kontrol odağı teorisi kapsamında ele alınmaktadır. Bu doğrultuda soru formları aracıllğılla ilgili kavramlara yönelik bir uygulama yapılmıstır. Elde edilen veriler analiz edilerek sonuç bölümünde çeşitli öneriler sunulmaktadır.

\section{Kuramsal Çerçeve}

Bilimsel araştırmalar geleneksel teoriler ile araştırma modelleri esas alınarak oluşturulmalıdır. Bilimsel araştırmada bir teori ve modelin belirttiği yöntemler dikkate alınarak hipotez kurulur ve bu hipotezler test edilir (Yıldırım, 1999). Bu kapsamda araştırma sosyal bilişsel teori ve kontrol odağı ilkesine dayandırılmaktadır.

Araştırmanın dayandırıldığı ilk teori olan sosyal bilişsel teoride insanların ahlak temsilcileri oldukları varsayllarak içsel ahlaki kurallarla ilişkili bireylerin sürekli kendilerini izledikleri, eylemlerini ve tepkilerini ahlaki kurallar çerçevesinde düzenledikleri öne sürülmektedir. Bu ahlaki kurallar gelişmeye yönelik tecrübeler ve sosyal etkileşimler sonucu öğrenilen standartlar, kurallar ve değerlerden oluşmaktadır (Johnson ve Buckley, 2015). Bu çerçevede öğrenme teorisi olarak da adlandırılan sosyal bilişsel teoriye göre davranışın nedenlerini anlama çevresel etkenlere odaklanmakla gerçekleşmektedir (İnanç ve Yerlikaya, 2017, s.209). Diğer yandan bu teori davranışsal teorilerin tam olarak açılkayamadı̆̆ eleştiriler doğrultusunda geliştirilen teori olarak da görülmektedir (Bayrakçı, 2007, s.198). Sosyal bilişsel teori çerçevesinde bireyler bilişsel kararları sonucunda kendilerini, davranış ve çevrelerini şekillendirmektedirler (Claybourn, 2011). 
Bireyler kendi davranışları ile başkalarının davranışlarını yargılamak amacıyla iç ahlak standartları geliştirirler. Bu standartların geliştiği bilişsel süreç öz düzenleme olarak nitelendirilmektedir. Bireyin ahlaki standartlarına uymayan aykırı davranışlarında öz denetim devreye girerek eleştiri ve kınama durumu ile suçluluk hisleri meydana gelmektedir. Bununla birlikte ahlaki standartlara uyum pozitif öz değerlendirme olarak nitelendirilmektedir. Bu sonuca göre öz değerlendirme çevresel koşullara göre değişmektedir (Bandura vd., 1996; Ağırbaş, 2019, s.6). Diğer yandan Bandura (1999) bazı durumlarda bireylerin öz denetim mekanizmalarının devre dışı kalacağını belirtmektedir. Öz değerlendirme süreçleri aktif olduğunda bireylerin kendilerini kınama ve doğru davranışlar sergileme eğiliminde oldukları belirtilirken aksi durumun ahlaki çözülmeye sebep olacağı da belirtilmektedir (Austin \& Vancouver, 1996; Detert vd., 2008; Ağırbaş, 2019). Bu çerçevede A tipi kişilik özelliği gösteren bireylerin kariyerlerini geliştirme noktasında daha aceleci olacakları bilinmekle birlikte bu kişilerin öz denetim mekanizmalarını devre dışı bırakarak amaçlarına daha hızlı ulaşma çabaları diğer bir ifadeyle meşru olmayan yollardan amaçlarına ulaşma çabaları içinde olacakları düşünülmektedir.

Araştırmanın dayandırıldığı ikinci teori olan kontrol odağı ilkesinde, insanların davranışlarını açıklamada iki genel eğilimden söz edilmekle birlikte bu eğilimlerin birincisi insanın kendinden kaynaklanan davranış biçimiyle diş çevreden kaynaklanan güçlerin olduğu bilinmektedir (Rotter vd., 1972, s.260-261). Bununla birlikte Rotter (1966, s.1-2) tarafindan öne sürülen kontrol odağı ilkesi sosyal öğrenme teorisindeki bir yapıya atıfta bulunarak bireylerin başlarına gelen olayların sebeplerini değerlendirmede farklı etkenler aradıklarını öne sürmektedir. Bu farklılaşmanın kaynağının ise kişilik özellikleri ve tecrübe edilmiş geçmiş olaylarla bağlantısı olduğu düşünülmektedir. Bununla birlikte Rotter (1966, s.2)'in tanımladığ1 kontrol algısı kavramında bireyin elde edeceği ceza ve ödüllerin kişinin kendisi aracıllğ̆yla mı yoksa kendi dışındaki faktörler tarafından $\mathrm{m}$ denetlendiğine ilişkin beklentileri olarak da tanımlamaktadır. Lefcourt (1991) kontrol odağ1 ilkesi olarak tanımladığ1 bu kavramı iki tip insan davranışı olarak belirtmektedir. Birinci tipe göre bireyler zor koşullarda gönüllü ve aktif bir biçimde çaba sarf ederek sorunların üstesinde gelmeye çabalarken ikinci tip bireylerin olumsuz durumlarda olumsuz duygulara kolaylıkla kapılarak etkilendiklerini belirterek bunun nedenlerini bireylerin iç durumlarındaki farklılıklardan kaynaklandığını belirtmektedir. Kontrol odağı ilkesi, bireylerin kendi davranışlanı hakkında kontrole sahip olduklarını veya bu davranışların başka bir faktör olan kader, talih, şans gibi kendileri dışındaki güçlerin kontrolü altında olduğunu belirtmektedir (Freedman vd., 1993).

\section{Kavramsal Çerçeve}

\subsection{A tipi Kişilik Özelliği}

Sağlık alanında yapılan araştırma ve muayenelerde kalp damar hastalıkları olan hastaların \%50'sinin hastalı̆̆ın belirtileri olan standart risk faktörlerini taşımadıkları halde kalp hastalı̆̆ına yakalandıkları gözlemlenmiştir. Bu verilerden yola çıkan kalp doktorları, 35 ila 39 yaş aralığında olan 3524 erkek bireyleri belirli bir süre gözlemlemişlerdir (Friedman \& Rosenman, 1974, s.67-68). Gözlemleri sonucunda hastaların yarısının belirli davranışlar sergileme eğiliminde olmaları nedeniyle hastalık belirtileri gösterdiklerini, hastalık sebebinin belirli davranış biçimlerinden kaynaklandığını belirtmişlerdir (Aksoy, 2009). Bu araştırmalar ışığında yapılan tespitlere göre bireylerin davranış biçimleri ile kişilik özelliklerinden dolayı bazı sağlık problemleriyle karşılaştıkları görülmekle birlikte bu durumun kişinin kişilik özelliklerinden kaynaklandığı da düşünülmektedir (Friedman ve Rosenman, 1974).

Kişilik insanların davranış, duygu ve düşüncelerine yön veren zihinsel, duygusal ve fiziksel yönlerden birçok farklılık gösteren özellikler bütünü olmakla birlikte A ve B tipi kişilik özellikleri olarak ikiye ayrılmaktadır. A tipi kişilik özelliği sergileyen bireyler sabırsız, kendilerini işlerine adamış işsolik, aşırı rekabetçi ve zamana karşı duyarlı bireyler olarak nitelendirilir. Diğer yandan B tipi kişilik özelliğine sahip bireyler ise yaşamlarında daha dengeli davranış sergileyen zaman kavramıyla çatışmayan daha rahat yaklaşım sergileyen bireyler olarak tanımlanmaktadır (Durna, 2005, s.275). Araştırma kapsamında A tipi kişilik özelliği ele alınmakla birlikte Lelord ve Andre (1996)'ye göre A tipi kişilik özelliği gösteren bireylerin saldırgan, rekabetçi, zamanla yarış gösteren bireyler oldukları belirtilmekte, bu kişilerin günlük hayattaki sıradan olaylarda bile sinirlendikleri ve stres yaşadıkları diğer bir ifadeyle strese eğilimli bireyler oldukları belirtilmektedir. 
A tipi kişilik özellikleri stres araştırmalarında sıklıkla araştırılan bir konu olmakla birlikte (Lelord \& Andre, 1996) bireylerin yaşadıkları hayat, iş yeri şartları ile stresli olayların yoğunluğu ve sıklığı birbirleriyle etkileşerek bireyleri bu tip kişilik özelliğine dönüştürdügü de belirtilmektedir (Jung, 1999; Kirkcaldy vd., 2002; Marten \& Wilkerson, 2003; Crust, 2020). Diğer yandan A tipi kişilik özelliği gösteren bireylerin bazi sağlık problemleri de yaşadıkları bilinir. Bu bireylerin kişilik özellikleri gereği strese dirençlerinin az olması ve yoğun strese maruz kalmaları gibi nedenlerden dolayı kalp damar hastalıklar ile baz1 psikolojik sorunlar yaşadıkları belirtilmektedir (Friedman \& Rosenman, 1971; Al-Mashaan, 2001; Kojima vd., 2004; Battgün \& Şahin, 2006; Larkin \& Chantler, 2020; Mori vd., 2020).

\subsection{Kariyerizm}

Kariyer, bireylerin yaşamları süresince kazandıkları iş tecrübelerinin bütünü olarak tanımlanmaktadır (Güney, 2004, s.136; Gökdeniz \& Merdan, 2011; DeCenzo vd., 2017, s.196). Yönetim bilimi alanında her geçen gün önemi artan ve birçok araştırmacı tarafindan sürekli araştırılan bir konu olan kariyer kavramı çalışanların edinmiş oldukları tecrübe, yetenek veya eğitimsel niteliklere göre görevlendirilen, faaliyet alan ve niteliklerinin değişmesi durumları olarak ifade edilmektedir (Ak \& Sezer, 2018a, s.679-680). İrmiş ve Bayrak (2001, s.179) kariyeri, hiyerarşik örgütlerin kariyer merdivenlerinde dikey yönde yukarı doğru hareket etmek olarak tanımlamaktadır. Bu hareketle görevinde yükselen diğer bir ifadeyle kariyerinde hedeflediği yere yerleşen çalışanlar eski görevlerine göre daha geniş otorite ve yetkiye ulaşabilmekte ve bu sayede bu kişilerin mali ve özlük haklarında iyileștirmeler olabilmektedir (Ak \& Sezer, 2018b, s.740). Bu görüşlerde de görüleceği üzere kariyerin genelde olumlu olarak bireylerin maddi ve manevi kazanç elde ettikleri bir süreç olarak görülmesi nedeniyle birçok çalışanın ulaşma arzusuyla çabaladıkları bir süreç olarak da düşünülebilir. Bu çerçevede kariyer hedeflerine ulaşabilmek için çalışanların her türlü yola başvurdukları bilinir. Liman vd. (2019)'ne göre negatif bir kavram olarak görülmeyen kariyerin yanlış işletme ve yönetim politikaları nedenleriyle olumsuz bir hal alabileceği de belirtilmektedir. Alan yazında yapılan bazı çalışmalarda çalışma ortamındaki diğer bireylere zarar verme amaçlı gerçekleştirilen sapkın iş davranışları örgütsel davranışın karanlık yüzü (Andersson ve Pearson, 1999; Griffin vd., 2004) olarak ifade edilmekle birlikte kariyerizm de bu kavramlar arasında görülmektedir (Schilpzand vd., 2016).

Kariyerizm (careerism), örgütteki çalışanların kariyer hedeflerine uygun biçimde ilerleme arzularına uyarak ve meşru yöntemlerden uzaklaşarak kendi usul ve yöntemleriyle sürdürme eğiliminde olmaları olarak tanımlanmaktadır (Feldman \& Weitz, 1991, s.238). Aşırı veya uç kariyerizm olarak da ifade edilen kariyerizm kavramında çalışanlar itibar ve güç elde edebilmek amacıyla kariyerlerinde dikey yönde ilerlemeleri için görev performansları dışındaki zamanlarında olumlu veya olumsuz davranışlar sergilemektedirler (Bratton \& Kacmar, 2004; Yıldız \& Arda, 2018). Bu kapsamda çalışanların beklentilerinin karşılanmaması durumunda, örgütsel ve toplumsal değişim ile kişilik ve aile yapıları gibi birçok sebepler kariyer kavramını kariyerizm olarak olumsuz bir kavrama dönüştürmektedir (Üzüm, 2018; Akgemci vd., 2019).

Kariyerizm eğilimine sahip çalışanların kariyer ilerlemelerini sağlamak amacıyla performansa dayalı yöntemlere başvurmak yerine mesai arkadaşları ve yöneticiler ile iyi ilişkiler kurma, kendi reklamlarını yapma, sanki başarllımış gibi görünüm sergileme, amacına ulaşma noktasında örgüte veya örgüt üyelerine zarar verme noktasında herhangi bir sorun görmeyen halleri bulunabilmektedir (Feldman \& Weitz, 1991; Bandura, 1999; Christian \& Ellis, 2014; Moore, 2015; Erbaş \& Perçin, 2017; Ettekal \& Ladd, 2020) Buna ek olarak kariyerizm, örgüt çalışanlarının kariyer ilerlemeleri noktasında performansa dayalı olmadan başka yöntemlerle çabalarını sürdürme eğilimi olarak da nitelendirilmektedir (Saidon ve Ab Ghani, 2020).

Alan yazında kariyerizm hakkında yapılan birçok çalışma olmakla birlikte bu çalışmalar; kadınlar ile cinsiyetin kariyerizm ilişkileri (O'Leary \& Braun, 1972; Depner \& O'Leary, 1976; Bank, 2003; Townsend, 2005), askerlik ile ilişkilendiren (Hauser, 1984; Ficarrotta, 1988), üretkenlik karşıtı (Yıldız, 2015; Yıldız \& Alpkan, 2015) olarak nitelendirilmektedir.

\subsection{Ahlaki Çözülme Eğilimi}

Ahlaki çözülme eğilimi sosyo-bilişsel teoriden türeyen bir kavram olarak ortaya atıllmıştır (Erbaş ve Perçin, 2017). Ahlaki çözülme, bireylerin yapmayı düşündükleri doğru olmayan davranışların yanlış 
olduğunu bildikleri halde, bu yanlış davranışları kendi iç dünyalarında belirli bir mantık silsilesine sokarak sürdürme eğilimi içerisinde olmalarıdır (Bandura, 1999, s.197). Bu kapsamda bireyler, yaptıkları rasyonelleştirmeler sonucu, etik ve ahlak dışı davranışlarının sebep olacağı psikolojik rahatsızlığı hissetmemektedirler (Shaw vd., 2020). Bu duruma sebep olan dürtünün ahlaki çözülme eğilimi olduğu bilinmektedir.

Bandura (1999, s.206-207)'ya göre ahlaki çözülme eğilimi yüksek olan bireylerin yaptıklanı adaletsiz, gayri ahlaki yanlış davranışlardan rahatsızlık ve suçluluk duymadıkları ve ahlaklı olmayı emreden davranış mekanizma ve suçluluk duygularını devre dişı bırakarak toplum tarafindan istenmeyen davranışlar sergiledikleri belirtilmektedir (Bandura, 1999; Detert vd., 2008). Ağırbaş (2019, s.26) bireyin davranışlarının olumsuz yöne evirilmesinde öz denetim mekanizmasının devre dışı bırakılmasının öneminin büyük olduğunu belirtmektedir. Bu çerçevede Christian ve Ellis (2014, s.193) öz denetimin, kişinin kendi kendini kontrol etme mekanizması olduğunu, bireylerin öz denetimlerinde meydana gelen çöküşün, bu kişileri uygunsuz olan içgüdüsel eğilimlere yönlendirerek olumsuz davranışlar sergilemelerine neden olduğunu belirtmektedir. Bununla birlikte öz denetim bireyler tarafindan kullanılmadıkça işlevsel olmamaktadır. Seçici aktivasyon yoluyla bireyin yapması gereken davranışların gayri ahlaki davranışlara yönelmesi ile olumlu ve olumsuz davranışlar arasındaki bağ zayıflayabilmektedir (Bandura, 2014). Diğer bir ifadeyle ahlaki çözülme eğilimini ele alan Albert Bandura, sosyal bilişsel teori kapsamında ahlaki çözülme eğilimini, insanların doğru davranışlarıyla gayri ahlaki davranışları arasında kaldıkları ikilemden kurtulma nedenlerini açıklamaya yöneltmekte ve ahlaki çözülmenin insanların bilerek ve isteyerek ahlaki standartlardan uzaklaşmaları olarak ifade etmektedir (Gülmez \& Öner, 2016).

Alan yazında ahlaki çözülme hakkında yapılan çalışmaların sayılarının her geçen gün artması bu kavramın daha da araştırılacak bir konu olduğunu göstermektedir. İlgili yazında ahlaki çözülmenin sapkın davranış biçimi olarak tanımlandığı görülmektedir (Christian \& Ellis, 2014; Gini vd., 2020; Seriki vd., 2020). Ahlaki çözülme kavramı alan yazında; akran zorbalığ1 (Ettekal \& Ladd, 2020; Sjögren vd., 2020; Wang vd., 2020), örgütsel etik ile ahlak iklim (Detert vd., 2008; Moore vd., 2012; Perren \& GutzwillerHelfenfinger, 2012; Chen vd., 2020; Nusantara vd., 2020) ve örgütsel etik dişında olan davranışlar (Barsky, 2008; Yang vd., 2020) ile ilişkilendirilmektedir.

\subsection{A tipi Kişilik Özelliği, Kariyerizm ve Ahlaki Çözülme Eğilimi İlişkileri}

Alan yazında A tipi kişiliğe sahip bireylerin aceleci, rekabetçi, saldırgan ve zamanla yarışan bireyler olduğu belirtilmektedir (Şahin vd., 2009, s.245). Buna ek olarak A tipi kişilik özelliğine sahip bireylerin aşırı rekabetçi olmaları, kendilerini işe adayan iş kolik bireyler olmaları ve mümkün olduğu kadar başarıya çok kısa sürede ulaşmak isteyen, sabırsız bireyler olmaları (Moorhead \& Griffin, 1992) nedeniyle bu kişilerin kariyerlerine çabuk erişme eğiliminde oldukları düşünülmektedir. Aytaç (2002) bu kişilik özelliğine sahip bireylerin zamanı iyi yönetemediklerini de belirtmektedir. Bu görüşe göre A tipi kişilik özelliğine sahip bireyler zamanı yeterince ve verimli biçimde yönetememeleri nedeniyle uzun ve meşakkatli kariyer sürecini kolaylikla ve meşru olmayan yollara başvurarak geçirmeyi isteyeceklerdir. Bu nedenle A tipi kişilerin kariyerizm eğilimlerinin yüksek olacağı ve bu kişilerin ahlaki çözülmeye de yatkın olacakları düşünülmektedir. Bununla birlikte Bandura vd. (1996)'ya göre bireyler bazı durumlarda öz düzenleme mekanizmalarını devre dişı birakma yoluna girmektedir.

Ağırbaş (2019, s.45) performansa dayalı olmayan kariyer yükselme eğiliminde olan bireylerin sergiledikleri davranışlarda öz düzenleme mekanizmalarını devre dışında bıraktıklarını, bu kişilerin ortaya koydukları kariyerist eylemlerin sakıncalı olmadığı düşüncesi ile örgütlerde istenmeyen sonuçlara neden olacağını belirtmektedir. Bu kapsamda bu kişilik özelliğine sahip bireylerin hem kariyerizm eğilimleri hem de ahlaki çözülme eğilimlerinin yüksek olacağ1 düşünülmektedir.

\section{Yöntem}

\subsection{Araştırmanın Amacı ve Önemi}

Araştırmanın amacı; A tipi kişilik özelliği, kariyerizm eğilimi ve ahlaki çözülme ilişkilerini analiz etmektir. Bu kapsamda araştırmanın temel sorusu "A tipi kişilik özelliği, kariyerizm eğilimi ve ahlaki çözülmeyi ne yönde ve nasıl etkilemektedir?” olarak belirlenmiştir. 
Alan yazında A tipi kişilik özelliği ile ilgili (Friedman \& Rosenman, 1971; Friedman \& Rosenman, 1974; Al-Mashaan, 2001; Kirkcaldy vd., 2002; Kojima vd., 2004; Durna, 2005; Aksoy, 2009), kariyerizm ile ilgili (O'Leary \& Braun, 1972; Depner \& O'Leary, 1976; Hauser, 1984; Ficarrotta, 1988; Bank, 2003; Bratton \& Kacmar, 2004; Townsend, 2005; Yıldız, 2015; Yıldız \& Alpkan, 2015; Yıldız \& Arda, 2018; Akgemci vd., 2019; Liman vd., 2019) ve ahlaki çözülme eğilimi ile ilgili (Perren ve Gutzwiller-Helfenfinger, 2012; Bandura, 2014; Gülmez \& Öner, 2016; Erbaş \& Perçin, 2017; Ağırbaş, 2019; Wang vd., 2020; Yang vd., 2020) yapılan çalışmalar bulunmaktadır. Bu çalışmalar genelde diğer örgütsel davranış konuları ile ilişkilendirilirken her üç kavramın irdelendiği herhangi bir araştırmaya rastlanılamamıştır. Diğer yandan bu kavramlar hakkında yapılan araştırmaların oldukça kısıtlı olduğu ve genel olarak psikoloji alanında yapıldığı da görülmektedir. Bu kapsamda araştırmanın ilgili yazındaki boşluğu dolduracağı düşünülmektedir.

Ağırbaş (2019), bireylerin kişilik yapıları ile kariyerizm eğilimleri hakkında yapılan çalışmaların oldukça kısıtlı olduğunu belirterek kişilik ve kariyerizm eğilimlerinin ilişskili olduğu değişkenler arasında çıkarımlar yapılmasının faydalı olacağını belirtmektedir. Diğer yandan A tipi kişilik özellikleri ile kariyerizm ve ahlaki çözülmenin ilişkilendirildiği herhangi bir çalışmaya rastlanılamaması nedeniyle alan yazına yeni bir model kazandırılmasının sağlanacağı düşünülmektedir.

Araştırma çerçevesinden belirlenen araştırma sorusunu cevaplamak amacıyla Konya ilinde faaliyet gösteren özel bir bankanın çalışanlarına yönelik bir saha araştırması yapılmışır. Alan yazında A tipi kişilik özelliği, kariyerizm eğilimi ve ahlaki çözülme hakkında yapılan araştırmaların oldukça kısıtlı olduğu görülmektedir. Diğer yandan konuların üçünü de bir bütün olarak ele alan bir araştırma da tespit edilememiştir. Bu çerçevede araştırmanın A tipi kişilik özelliği, kariyerizm eğilimi ve ahlaki çözülmenin bir bütün halinde konu edilmesi araştırmanın özgün niteliği olarak gösterilebilir.

\subsection{Araştırmanın Evreni ve Örneklem Çerçevesi}

Araştırmanın evrenini Konya'daki özel bir bankada faaliyet gösteren çalışanlar oluşturmaktadır. Araştırma kapsamında örneklem çerçevesini bu bankanın Konya ili dâhilinde çalışanlar oluşturmakla birlikte bankanın Konya'daki bütün şubelerinde çalışan toplam 1000 kişi bulunmaktadır. Bu kapsamda araştırmanın evrenini 1000 çalışan oluşturmaktadır.

Araştırmaya ait veriler ilgili banka çalışanlarından kolayda örneklem yöntemiyle örneklem çerçevesi olarak 360 adet kullanılabilir soru formu araştırma kapsamında ele alınmıştır. Soru formlarının geri dönüş oranının yaklaşı \%36 olması araştırmanın bilimsel yeterliliği (Lewin vd., 1995) sağladığını göstermektedir.

$\mathrm{Bu}$ araştırmanın yapılabilmesi için Bolu Abant İzzet Baysal Üniversitesi Sosyal Bilimlerde İnsan Araştırmaları Etik Kurulu'ndan 25.06.2020 tarih ve 2020/06 numaralı toplantısında 2020/143 protokol numarası ile Etik Kurul İzni alınmışır. Araşı̧ıma etik ilke ve kurallara uyularak hazırlanmışır.

\subsection{Araştırmanın Modeli ve Hipotezler}

Araştırma kapsamında A tipi kişilik özelliği, kariyerizm eğilimi ve ahlaki çözülmeye ilişkin araştırma modeli Şekil 1'de gösterilmektedir.

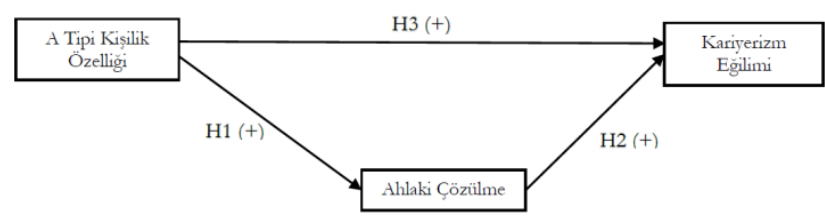

Şekil 1. Araştırma Modeli

Şekil 1'deki araştırma modeline göre kariyerizm eğilimi (bağımlı değişken), ahlaki çözülme (arac1 değişken) ve A tipi kişilik özelliği (bağımsız değişken) olarak kurgulanmışır. Araştırma modeli doğrultusunda aşağıdaki hipotezler geliştirilmiştir;

Hipotez 1: A tipi kişilik özelliğinin ahlaki çözülme eğilimi üzerinde pozitif yönlü anlamlı bir etkisi vardır.

Hipotez 2: Ahlaki çözülme eğiliminin kariyerizm eğilimi üzerinde pozitif yönlü anlamlı bir etkisi vardır.

Hipotez 3: A tipi kişilik özelliğinin kariyerizm eğilimi üzerinde pozitif yönlü anlamlı bir etkisi vardır. 
Hipotez 4: A tipi kişilik özelliğinin kariyerizm eğilimine etkisinde ahlaki çözülmenin aracı etkisi vardır.

\subsection{Araştırmada Kullanılan Ölçekler ile Güvenilitlik ve Geçerlilik Analiz Sonuçları}

Araştırmada kullanılan soru formu, araştırma ölçeklerinden oluşturulmuştur. Bu kapsamda Moore vd. (2012) tarafindan geliştirilen ve Türkçe' ye Erbaş ve Perçin (2017) tarafından uyarlanan 8 maddelik “Ahlaki Çözülmenin Etkisi Ölçeği” kullanılmıştır. Araştırmanın diğer değişkenleri olan Feldman ve Weitz (1991) tarafindan oluşturulup, Yıldız (2015) tarafindan Türkçe' ye uyarlanan 7 maddelik "Kariyerizm Eğilimi Ölçeği” ile Batıün ve Şahin (2006) tarafından oluşturulan 25 maddelik "A tipi Kişilik Özellik Ölçeği”" kullanılmıştır.

Araştırmada uygulanan ölçeklerin güvenilirliklerini test etmek için Cronbach Alfa testinden yararlanılmışır. Alfa katsayıları; A tipi kişilik özelliği ölçeği için $\alpha=0.967$, ahlaki çözülmenin eğilimi ölçeği $\alpha=0.892$ ve kariyerizm ölçeği $\alpha=0.967$ olarak belirlenmiştir. Bu sonuçlara göre ölçeklerin güvenilir olduğu söylenebilir.

Araştırma kapsamında yapılan temel bileşen analizine göre, tek faktörlü araştırma yapısının geçerliliğini sınamak amacıyla AMOS programı kullanılarak doğrulayıcı faktör analizi (DFA) uygulanmıştır. İyi uyum ve geçerlilik ölçüleri ile araştırma modeli Tablo 1'de gösterilmektedir.

Tablo 1. Model-Veri Uyum Değerleri

\begin{tabular}{|c|c|}
\hline Veri-model uyum indisleri & Kabul edilebilir uyum değerleri \\
\hline Ki-Kare $(\mathrm{X} 2)=1282,53$ & $\mathrm{SD}=631, \mathrm{p}<0.01$ \\
\hline GFI $=0.887$ & l'e yakın olursa iyi bir model kabul edilir (Tanaka ve Huba, 1985) \\
\hline $\mathrm{NFI}=0.917$ & l'e yakın olursa iyi bir model kabul edilir (Bentler ve Bonett, 1980) \\
\hline $\mathrm{CFI}=$ & l'e yakın olursa iyi bir model kabul edilir (McDonald ve Marsh, 1990) \\
\hline $\mathrm{TLI}=($ & l'e yakın olursa iyi bir model kabul edilir (Bentler ve Bonett, 1980) \\
\hline RMSEA $=0.054$ & 0.08 altında iyi bir model kabul edilir (Browne ve Cudeck, 1993) \\
\hline $\mathrm{CMIN} / \mathrm{SD}=2.033$ & 1 ile 5 arasında olmalıdır (Marsh ve Hocevar, 1985) \\
\hline \multicolumn{2}{|c|}{$\begin{array}{l}\text { Not: } \chi 2 \text {, Ki-Kare; SD, Serbestlik Derecesi, GFI = İyilik Uyum İndeksleri, NFI = Normalleştirilmiş } \\
\text { Uyum İndeksi, CFI = Karşılaştırmalı Uyum İndeksi, TLI, Tucker-Lewis indeksi; RMSEA = Yaklaşık } \\
\text { Hataların Ortalama Karekökü, X2/SD, Relative Ki-Kare. }\end{array}$} \\
\hline
\end{tabular}

$\mathrm{Bu}$ analize göre araştırmada elde edilen verilere 3 farklı ölçme modele göre test edilmiş, uyum indisleri X2/SD, RMSEA, TLI, GFI, NFI ve CFI değerli ile elde edilen sonuçlar ile iyi uyum ve geçerlilik ölçüleri Tablo 1'de gösterilmektedir. Tablo 1'de görülen 3 faktörlü modele yönelik $\chi 2$ değerinin anlamlı olduğu görülmektedir. Bunula birlikte, $\chi 2 / \mathrm{SD}$ değerinin $(2,03) 5$ 'in altında olması nedeniyle model geçerlilik açısından uyum ölçütünü sağlamaktadır. Bunun yanı sıra GFI $=0.887$, CFI $=0.956$, NFI $=0.917$ ve RMSEA $=0.054$ göstergeleri açısından da verilerin uyumlu olduğu görülmektedir (Tablo 1). Tek faktörlü model ile çok faktörlü model arasında karşılaştırmalı uyum tablosu Tablo 2'de belirtilmektedir.

Tablo 2. Karşılaştırmalı model uyumu

\begin{tabular}{cccc}
\hline Modeller & $\mathrm{X}^{2}$ & SD & $\Delta \mathrm{X}^{2}$ \\
\hline Tek Faktörlü Model & 6720.36 & 702 & - \\
3 Faktörlü Model & 1282.53 & 631 & 5437.83 \\
A Tipi Kişilik, Kariyerizm, Ahlaki Çözülme & & & \\
\hline
\end{tabular}

Araştırma kapsamında verilerin analizine göre tek faktörlü model ile çok faktörlü model arasındaki uyumu belirlemek amacıyla $\chi^{2}$ değerlerine "Ki-Kare Fark Testi" uygulanmış ve anlamlı bir farkın olduğu görülmüş̧ür. (Tablo 2'de). Bu sonuca göre 3 faktörlü model verileri daha iyi uyumlu olduğunu göstermektedir. Çalışmaya 3 faktörlü (ilişkili) model ile devam edilmiştir. Analizler kapsamında A tipi kişilik özelliği ölçeğine yönelik sorularda faktör yükü düşük olan 25. soru ile ahlaki çözülme ölçeğindeki 8 . soru analiz kapsamından çıkarılmıştır.

Araştırma kapsamında ele alınan ölçeklerim ölçülmesi ile değişkenlerin derecelerini değerlendirmek amacıyla yakınsama ve ıraksama ayırt edici geçerlilik analizleri yapılmıştır. Ele alınan bir modelin geçerliliğine yönelik yapının oluşturulduğu bütün değişsenlerin aralarındaki yüksek korelasyon görülen ilişki gösteren yakınsama (convergent validity) ile modelin değişkenlerinin diğer değişkenlerle düşük 
korelasyon ilişkisini gösteren ıraksama ayırıcı (discriminant validity) geçerliliğini sağlaması gerekmektedir (Churchill Jr, 1979; Akdeniz, 2018; s. 41). Araştırma verilerine göre kullanılan araçların modeli ölçmesi yönünden yakınsama ve 1raksama ayırt edici geçerlilikleri incelenmiştir (Tablo 3).

Tablo 3. Değişkenlere Ait Ortalama, Standart Sapma, Güvenirlilik ve Korelasyon Değerleri

\begin{tabular}{clcccccccc}
\hline & Değişkenler & Ort & S.S. & $\alpha$ & CR & AVE & 1 & 2 & 3 \\
\hline 1. & A Tipipi Kişilik & 3.64 & .982 & .947 & .978 & .650 & - & & \\
2. & Kariyerizm & 3.68 & .914 & .911 & .967 & .807 & $.525^{* *}$ & - & \\
3. & Ahlaki Çözülme & 3.62 & .943 & .925 & .935 & .675 & $.134^{*}$ & .017 & - \\
\hline standart sapma; ${ }^{*} 0,05$ düzeyinde anlamlıdır (çift-yönlü), ${ }^{* * 0,01}$ düzeyinde anlamlıdır (çift-yönlü)
\end{tabular}

Tablo 3'te ilgili ölçeklerden elde edilmiş veriler için, AVE değerlerine göre yakınsama geçerliliği belirtilmektedir. Bülbül ve Demirer (2008)'e göre yakınsama geçerliliği, araştırma yapısını ölçen boyutların yapının parçası olarak sayılabilmesi için kendi arasından belirli düzeyde korelasyonun bulunması gerekir. Diğer yandan modelin AVE değerinin 0,5 değerinden yüksek olması ilgili maddelerin örtük değişkenlerinin geçerli olduğunu göstermektedir. Tablo 3'te görüleceği üzere AVE değerlerinin 0,5'ten yüksek olması ile yakınsama geçerliliği sağlanmaktadır (Fornell \& Larcker, 1981; Hu \& Bentler, 1999). Ayırt edici geçerliliğin belirlenebilmesi amacıyla değişkenler arası korelasyon değerinin 0,80'den küçük olması 1raksama, ayırt edici geçerliliğin sağlandı̆̆ını gösterir (Kline, 2014; Abubakar \& Ilkan, 2016). Tablo 4'te görüleceği üzere korelasyon değerlerinin 0,80 'den düşük olması ve anlamlı bir ilişkinin olduğunun görülmesi nedeniyle ıraksama ayırt edici geçerliliği sağlanmıştır. Tablo 3'e göre A tipi kişilik özelliği ile kariyerizm arasındaki ilişki incelendiğinde, anlamlı ve pozitif yönde olduğu gözlemlenmiştir ( $\mathrm{r}=.525, \mathrm{p}<.001)$. A tipi kişilik özelliği ile ahlaki çözülme arasındaki ilişkinin istatistiki yönden anlamlı olduğu gözlemlenmiştir $(\mathrm{r}=.134$, $\mathrm{p}<.005)$. Son olarak kariyerizm ile ahlaki çözülme arasındaki korelasyon değerleri incelendiğinde aralarında anlamı bir ilişki bulunmamaktadır $(\mathrm{r}=.017, \mathrm{p}>.005)$.

\section{Araştırma Bulguları}

\subsection{Demografik Bulgular}

Araştırmadaki katılımcıların cinsiyet, eğitim düzeyi, yaş ve kıdem gibi demografik bilgileri, Tablo 4'te açıklanmaktadır.

Tablo 4. Demografik Bulgular

\begin{tabular}{|c|c|c|c|c|c|}
\hline Cinsiyet & $\bar{F}\left(S_{1} k_{1} 1 \mathrm{k}\right)$ & \% Yüzde & Medeni Durum & F (S1klık) & \% Yüzde \\
\hline Kadin & 156 & 43.3 & Bekâr & 122 & 33.9 \\
\hline Erkek & 204 & 56.7 & Evli & 238 & 66.1 \\
\hline Toplam & 360 & 100.0 & Toplam & 360 & 100.0 \\
\hline Yaş & F (S1klık) & \% Yüzde & Eğitim Düzeyi & F (S1klık) & \% Yüzde \\
\hline $18-25$ & 68 & 18.9 & Lise\&Dengi & 28 & 7.7 \\
\hline $26-35$ & 74 & 20.6 & Ön Lisans & 127 & 35.2 \\
\hline $36-45$ & 98 & 27.2 & Lisans & 175 & 48.7 \\
\hline $46-55$ & 73 & 20.3 & Lisansüstü & 30 & 8.4 \\
\hline 56- üstü & 47 & 13.0 & & & \\
\hline Toplam & 360 & 100.0 & Toplam & 360 & 100.0 \\
\hline
\end{tabular}

Tablo 5'te katılımcıların \%43,3'ü kadınlardan, \%56,7'si erkeklerden oluşmaktadır. Medeni durumlarına bakıldığında katılımcıların \%33,9'unun bekâr, \%66,1'unun evli olduğu belirlenmiştir. Eğitim düzeylerine göre dağılım incelendiğinde katılımcıların \%7,7'si lise ve dengi, \%35,2’ ön lisans, \%48,7'si lisans ve \%8,4'ü ise lisansüstü derecesine sahip personellerden oluştuğu görülmektedir. Yaş aralığına göre katılımcıların \%27,2’ sinin, 36-45 yaş aralığında yoğunlaştı̆̆ı görülmektedir. Diğer yaş oranları ise \%18,9'u 18-25 yaş, \%20,6’s1 26-35 yaş aras1, 46-55 yaş ve üzeri \%20,3'ünü ve \%13'ü ise 56-üstü personelleri kapsamaktadır. 


\subsection{Araştırma Hipotezlerinin Test Edilmesi}

Araştırma kapsamında hipotezlerin test edebilmesi için araştırma değişkenlerine yapısal eşitlik modeli analizi uygulanmıştır. Tablo 5’te A tipi kişilik özelliği, kariyerizm ve ahlaki çözülme eğilimine ilişkin yapısal eşitlik modeli sonuçları görülmektedir.

Tablo 5. Doğrudan Etki

\begin{tabular}{|c|c|c|c|c|}
\hline Değişkenler & $\beta$ & $\mathrm{t}$ değeri & SH & $\mathrm{p}$ \\
\hline A tipi Kișilik Özelliği - Ahlaki Cözülme & .017 & .317 & .049 & .751 \\
\hline Ahlaki Cözülme - Kariyerizm & 125 & 11.768 & .058 & $* * *$ \\
\hline A tipi Kişilik Özelliği - Kariyerizm & .523 & 2.822 & .054 & *** \\
\hline
\end{tabular}

Tablo 5’ e göre A tipi kişilik özelliğinin ahlaki çözülme üzerinde anlamlı bir etkisinin olmadığ1 görülmektedir $(\beta=.017, \mathrm{t}=.317, \mathrm{p}=0.751>0.01)$. H1 hipotezi desteklenmemektedir. Ahlaki çözülme eğiliminin kariyerizm eğilimi üzerinde anlamlı bir etkisinin olduğu belirlenmiştir $(\beta=.125, t=11.768$, p <0.01). H2 hipotezi desteklenmektedir. Araştırmanın üçüncü hipotezi olan A tipi kişilik özelliğinin kariyerizm eğilimi üzerinde anlamlı bir etkisinin bulunduğu belirlenmiştir $(\beta=.523, \mathrm{t}=2.822, \mathrm{p}<0.01)$. H3 hipotezi desteklenmektedir.

Araştırmanın üçüncü hipotezinde A tipi kişilik özelliğinin kariyerizm eğilimine etkisinde ahlaki çözülme eğiliminin arac1 etkisi incelenmektedir. MacKinnon vd. (2007, s.594)'a göre aracı değişken, iki değişken arasında bulunan neden sonuç ilişskisini belirlemek amacı ile kullanılan analiz yöntemidir. Araștırmada aracılık etkinin ölçülmesi için; 1) Bağımsız değişkenin aracı değişkene etkisinin bulunması gerekmektedir. 2) Bağımsız değişkenin bağımlı değisskene etkisinin olması gerekmektedir. 3) Aracı değişkenin bağımlı değişkene etkisinin olması gerekmektedir, şartlarını sağlaması gerekmektedir (Baron ve Kenny, 1986). Araşıırma kapsamında değişkenlere yönelik aracı etkiyi belirlemek amacıyla araştırma değişkenlerine Yapısal Eşitlik Modeli uygulanmıştır. Bu kapsamda Tablo 6'da aracı etki değerleri belirtilmektedir.

Tablo 6. Arac1 etki

\begin{tabular}{|c|c|c|c|c|}
\hline Değişkenler & Toplam Etki & Doğrudan Etki & Dolaylı Etki & $\mathrm{p}$ \\
\hline A tipi Kișilik Özelliği - Ahlaki Çözülme & .017 & .017 & - & \\
\hline A tipi Kişilik Özelliği - Kariyerizm & .525 & .523 & .002 & .509 \\
\hline Kariyerizm - Ahlaki Çözülme & 125 & 125 & - & \\
\hline
\end{tabular}

Tablo 6' de araştırmanın aracı etkisi belirlenmiştir. A tipi kişilik özelliğinin kariyerizm eğilimine etkisinde ahlaki çözülmenin aracı etkisinin olmadığı görülmektedir. H4 hipotezi desteklenmemektedir. $(\mathrm{p}=0.509>0.001)$.

\section{Sonuç ve Tartışmalar}

Bireylerin kişilik özelliklerine göre davranışlarının farklı değişkenlere göre şekillendiği bilinmektedir. Bu noktada istihdam edilen çalışanların davranışlarının örgütleri bağlayıcı etkisinin olması kaçınılmazdır. A tipi kişilik özelliği gösteren bireylerin kariyer hedeflerine daha hızlı erişmek isteyecekleri fikrinden yola çıkılarak örgütlerin kariyer planlama aşamalarında daha adil ve liyakate uygun insan kaynakları politikası belirlemeleri önem arz etmektedir. Şahin (2016) Türkiye'de performansa dayalı olmayan kariyer yükselmelerinin sürekli arttığını, verilen görevlerin liyakate uygun olmasından dolayı işlerin nitelikli insanlara verilmesi gerekliliğini belirtmektedir. Bu çerçevede örgütlerin kariyer planlama politikalarının adil biçimde yapılmaması diğer bir ifadeyle görevlerin ve kariyerlerin hak eden uzman çalışanlara verilmemesi durumlarında çalışanların etik olmayan yollara başvurabilmeleri muhtemeldir. Bu kapsamda kariyer hedeflerini gerçekleştirmek isteyen bireylerin kendilerine uygun ve ahlaki değerleri yok sayabilecek yollara başvurabilecekleri düşünülmektedir. Liyakate uygun olmayan istihdam politikaları benimsemenin örgütler açısından olumsuz etkiler oluşturacağı da söylenebilir. 
Araştırma kapsamında A tipi kişilik özelliği, kariyerizm eğilimi ve ahlaki çözülme eğilimleri etkileşimleri incelenmektedir. Bu amaç doğrultusunda Konya ilinde özel bir banka çalışanlarına yönelik bir uygulama yapılmıştır. Elde edilen veriler analiz edilerek değerlendirmeler yapılmıştır.

Alan yazında A tipi kişilik özellikleri hakkında yapılan çalışmalarda (Friedman ve Rosenman, 1971; Friedman ve Rosenman, 1974; Al-Mashaan, 2001; Kirkcaldy vd., 2002; Kojima vd., 2004; Durna, 2005; Aksoy, 2009; Şahin vd., 2009) bu tip özelliğe sahip olan bireylerin genel olarak olumsuz davranışlarda bulunma eğilimlerinin yüksek olduğu belirtilmektedir. Diğer yandan ahlaki çözülme eğilimi hakkında yapılan çalısmalarda (Moore vd., 2012; Perren ve Gutzwiller-Helfenfinger, 2012; Christian \& Ellis, 2014; Johnson \& Buckley, 2015; Üzüm, 2018; Yıldız \& Arda, 2018; Ağırbaş, 2019; Liman vd., 2019; Ettekal \& Ladd, 2020; Wang vd., 2020; Yang vd., 2020) ahlaki çözülmenin yıkıcı ve sapkıı örgüt davranışlarına sebep olduğu belirtilmektedir. Araştırmanın diğer bir değişkeni olan kariyerizm eğilimi hakkında yapılan araştırmalarda (O'Leary \& Braun, 1972; Depner \& O'Leary, 1976; Hauser, 1984; Ficarrotta, 1988; Feldman \& Weitz, 1991; Chay \& Aryee, 1999; Bank, 2003; Bratton \& Kacmar, 2004; Townsend, 2005; Y1ldız vd., 2015b; Akgemci vd., 2019; Liman vd., 2019) kariyerizm eğiliminin yine sapkın örgüt davranışları arasında olduğu belirtilmektedir. Alan yazındaki araştırmalara göre A tipi kişilik özelliği, kariyerizm ve ahlaki çözülme eğiliminin yıkı1 ve sapkın örgüt davranışları olmaları nedeniyle bu kavramların birbirlerini pozitif yönde etkilediği düşünülerek araştırma hipotezleri oluşturulmuştur.

Araştırma bulgularında A tipi kişilik özelliğinin ahlaki çözüme üzerinde anlamlı bir etkisinin olmadığ1 ( $p>0.01$ ) belirlenmiştir. Bu sonuç alan yazında yapılan araştırmalarla örtüşmemektedir. Diğer yandan ahlaki çözülme eğiliminin kariyerizm eğilimi üzerinde anlamlı bir etkisinin olduğu $(p<0.01)$ ve A tipi kişilik özelliğinin kariyerizm eğilimi üzerinde anlamlı bir etkisinin bulunduğu belirlenmiştir $(\mathrm{p}<0.01)$. Elde edilen bu sonuçların alan yazında yapılan araştırmalarla örtüştüğü sonucuna ulaşılmıştır.

Sosyal Bilişsel Teoriye göre örgütte çalışanlar öz denetim hislerini devre dışı bırakmaları suretiyle örgütü etkileyen olumsuz ve sapkın örgüt davranışlarına yönelecekleri düşüncesiyle kariyerizm eğilimine yönelecekleri ve kariyer hedeflerine daha hızlı erişebilmek için ahlaki çözülme eğiliminde bulunabilecekleri belirtilmektedir (Ağırbaş, 2019; 71). Bu çerçevede alan yazında ahlaki çözülmenin aracı etki görevi gören çalısmaların (Detert vd., 2008; Hyde vd., 2010; Moore, 2015; Yıldız vd., 2015a; Ağırbaş, 2019; Seriki vd., 2020; Wang vd., 2020) olduğu görülmektedir

Araştırma bulgularına göre A tipi kişilik özelliğinin kariyerizm eğilimine etkisinde ahlaki çözülmenin aracı etkisinin bulunmadığı belirlenmiştir $(\mathrm{p}>0.001)$. Bu sonucun alan yazındaki diğer araştırmalarla örtüşmediği görülmektedir. Bu kapsamda ahlaki çözülme eğiliminin kariyerizm eğilimini güçlendirdiği, A tipi kişilik özelliğinin de kariyerizm eğilimini arttırdığı söylenebilir. Bu bulgulara göre örgütte görev yapan A tipi kişilik özelliğine sahip bireyler gözlemlenerek bu bireylerin kariyer hedeflerine ulaşmaları diğer çalışanların da gözetilmesi suretiyle adil bir şekilde desteklenmesi gerekmektedir. Ayrıca adaletli bir yönetimle çalışanların ahlaki çözülme eğilimler azaltılarak kariyerizm davranışı göstermeleri de engellenebilecektir.

Araştırma sonuçları değerlendirildiğinde kariyerizm eğilimi ve ahlaki çözülme eğilimlerinin en aza indirilmesi örgütün gelişmesine katkı sağlayacak ve çalışanların örgüte yönelik örgütsel davranışlarına olumlu yönde etkisi olacaktır. Diğer yandan çalışanların kişilik özelliklerinin belirlenmesi örgütün işleyişi açısından önem arz etmektedir. Bu noktada A tipi kişilik özelliğine sahip bireylerin sahip oldukları kişilik özellikleri gereğince bu kişilere daha dikkatli davranarak kişiler arası ilişkilerin geliştirilmesi ancak örgütte adil bir kariyer politikasının belirlenmesiyle olacağı söylenebilir. Özellikle gelecekte örgütsel sorunların yaşanmaması adına işe alım sürecinde istihdam edilecek bireylerin kişilik özelliklerinin belirlenmesi önemlidir. İşe alım sürecinde kişilik testi yapılması, adaylardan referans istenmesi gibi durumlar doğru çalışanın istihdam edilmesi noktasında önemli olabilir. Bu sayede çalışanların kişilikleri yönünden tanınma imkânı elde edilerek bu kişilerin örgütte daha verimli çalışmaları, performans ve motivasyonlarının artması sağlanacaktır. Diğer yandan işe uygun kişilerin istihdam edilmesiyle örgütte yıkıcı ve sapkın davranış eğilimleri olan kariyerizm ve ahlaki çözülme gibi durumlar en aza indirilebilecektir. Diğer yandan örgütler açısından özellikle A tipi kişilik özelliğine sahip çalışanların sergiledikleri kişilik özellikleri dikkate alınarak örgüt politikalarının belirlenmesinin uygun olacağı düşünülmektedir. 
Bu çalışma özel bir banka ile sınırlı tutulmuştur. Yapılan bu çalışma kamuya ait farklı bir bankada yapılarak sonuçlar bu araştırmayla kıyaslanabilir. Buna ek olarak diğer sektörlerde de benzer çalışmalar farklı örneklemlerde tekrarlanabilir. Çalışmada sadece özel banka çalışanlarına yönelik uygulama yapılmışıır. Banka çalşsanları dışında farklı meslek gruplarına yönelik uygulamalar yapılarak karşılaştırmaların yapılması faydalı olacaktır. Diğer yandan araştırmanın sadece Konya ile sınırlı kalması yapılacak değerlendirmelerin sadece Konya ili ölçeğinde geçerli olacağını düşündürmektedir. Bu noktada farklı il ve bölgelerde çalışma yapılması öneri niteliğinde olmaktadır. Bununla birlikte araştırma kapsamında ele alınan kavramlar örgütsel davranışının diğer konularıyla da ilişkilendirilmesi başka bir öneri olarak sunulabilir.

\section{Extended Abstract}

\subsection{Aim and Scope}

It is known that organizational resources that cannot be imitated are human resources. Human resources, which are seen as important actors for organizations to compete against their competitors, should be used most efficiently. Organizations need to provide employees opportunities to improve themselves in terms of skills and knowledge and be supported in career development. At this point, the personality traits of employees in organizations are important. Personality is defined as the concept that individuals have from birth and that they shape by earning throughout their lives, which distinguishes them from other people.

On the other hand, it is a situation that explains individuals' behaviors in different situations they encounter. The most important factor in determining the employees' career goals in the organization is these people's personality traits. In this context, determining the personality traits of employees is important for organizations. The research focuses on individuals with Type A personalities who are impatient and want to reach the goal as soon as possible. It is thought that these people may resort to inappropriate methods in order to reach their career goals rather than an ethical and legal process. In this context, it can be said that individuals with Type A personality traits may tend to morally dissolve and, in this case, also tend to be careerist. The research's main purpose is; Type A personality trait is to analyze the relationships between careerism tendency and moral dissociation tendency. In this context, the research's main question is "In what direction and how does Type A personality trait affect careerism tendency and moral dissolution?" as determined. Within the research scope, the relationships between the A-type personality trait of the concept of careerism and its moral disintegration tendencies are discussed within the scope of social cognitive theory and locus of control theory.

\subsection{Methods}

This research, which is designed according to the relational scanning model, one of the general scanning models, has been constructed with the quantitative research method. In the study, a sample of private bank employees $(\mathrm{n}=360)$ in Konya (Turkey) was applied. The data were obtained from bank employees through a questionnaire using the convenience sampling method. Within the scope of the study, "Type A personality trait" was constructed as the independent variable, "careerism tendency" as the dependent variable, and "moral disintegration tendency" as the mediator variable. Statistical analyzes were made on the obtained findings with SPSS and AMOS programs. Cronbach Alpha coefficient test was used to determine the reliability of the scales. Confirmatory Factor Analysis was performed on the data to determine the research model validity. According to research hypotheses, Structural Equation Model Analysis, Chi-Square Difference Tests, and Correlation Analysis analyses were applied.

\subsection{Findings}

The following findings were obtained from the analysis. The findings obtained from the relevant bank employees within the scope of the study;

- Type A personality trait has been found to have no significant effect on moral dissociation $(\mathrm{p}=0.751>0.01)$. 
- It has been determined that the moral dissolution tendency significantly and positively affects careerism tendency $(\mathrm{p}<0.01)$.

- Type A personality trait has been found to have a positively effect on careerism tendency $(\mathrm{p}<0.01)$

- It has been determined that moral disintegration has no mediator effect on the effect of Type A personality trait on careerism tendency $(\mathrm{p}=0.509>0.001)$.

\subsection{Conclusion}

It is known that individuals' behaviors are shaped according to different situations according to their personality characteristics. At this point, the behaviors of employees employed in organizations inevitably have a binding effect on organizations. Within the study's scope, the idea that individuals with Type A personality traits would want to achieve their career goals faster was set out. Organizations need to determine a more just and competent human resources policy in their career planning stages. The research findings determined that Type A personality trait increased the tendency to careerism, and the moral disintegration tendency strengthened the careerism tendency. On the other hand, it has been determined that the moral disintegration tendency does not have a mediating role in the effect of Type A personality trait on careerism tendency. According to these findings, individuals with Type A personality traits working in the organization should be observed, and these individuals should be supported fairly by taking into account other employees to reach their career goals. Besides, with fair management, the employees' moral disintegration tendencies can be reduced, and careerism can be prevented. Employees are likely to resort to unethical ways in cases where career planning policies are not made fairly and not assigned to the organization's work specialist. In this context, it can be said that individuals who want to achieve their career goals can resort to suitable ways and ignore moral values. Organizations need to adopt employment policies appropriate to merit. Also, it is a recommendation for organizations to determine organizational policies by taking into account the personality traits exhibited by employees with type A personality traits.

\section{Kaynakça}

Abubakar, A. M. ve Ilkan, M., (2016). Impact of online WOM on destination trust and intention to travel: A medical tourism perspective, Journal of Destination Marketing \& Management, 5 (3); 192-201.

Ağırbaş, Z. B., (2019), Nevrotik Kişilik Özelliğinin Kariyerizm Eğilimi Üzerindeki Etkisinde Ablaki Çözü̈lmenin Aracı Etkisi, İstanbul Üniversitesi Sosyal Bilimler Enstitüsü Işletme Anabilim Dali Yüksek Lisans Tezi.

Ak, M. ve Sezer, Ö., (2018a). Kamu Sektöründe Görevde Yüleselme (Kariyer): 11102011 Tarıb Ve 663 Saynl KHK Kapsamında Yapılandırlan Kamu Sağlık Sektöründe Calısanlarn Görevde Yükselme Sustemine Ilişkin Adalet Algzlarmm Kıdeme Göre Analizi, Third Sector Social Economic Review, 53 (2); 678-709.

Ak, M. ve Sezer, Ö., (2018b). Kamu Personel Sisteminde Çalışanların Görevde Yükselmesinde Kayırmacillk Sorunu, Suleyman Demirel University Journal of Faculty of Economics \& Administrative Sciences, 23.

Akdeniz, T., (2018). Boreout iş performans ü̈rerindeki etkisinde işe bağhllk aracu rolü ve cinsiyet düzenleyici rolï, Aksaray Üniversitesi Sosyal Bilimler Enstitüsü, Yüksel Lisans Tezi.

Akgemci, T., Makharadze, I., ve Kiziloglu, E. (2019). The Effect of Careerism Orientation on Organizational Justice Perception and Job Stress: An Application on Academic Staff. In RSEP CONFERENCES (p. 39).

Aksoy, Ö., (2009). Öğretmen ve Okul Yöneticilerinde A Tipi Kişilik Özellikleri İle Tükenmişslik İliskileri ve Bayrampașa İlgesinde İlkögretim Okullarnda Yapılan Bir Uygulama, Beykent Üniversitesi Sosyal Bilimler Enstitüsü İşletme Yönetimi Anabilim Dalı Eğitim Yönetim Denetimi Bilim Dalı, Yüksek Lisans Tezi, İstanbul.

Al-Mashaan, O. S., (2001). Job stress and job satisfaction and their relation to neuroticism, type A bebavior, and locus of control among Kuwaiti personnel, Psychological Reports, 88 (3_suppl); 1145-1152.

Andersson, L. M. ve Pearson, C. M., (1999). "Tit for tat? The spiraling effect of incivility in the workplace", Academy of management review, 24 (3); 452-471.

Austin, J. T. ve Vancouver, J. B., (1996). Goal constructs in psychology: Structure, process, and content, Psychological bulletin, 120 (3); 338.

Aytaç, T., (2002). Eğitim ve Yönetimde Yeni Yaklaşımlar Zaman Yönetimi, Bilim ve Aklın Aydınlğında Eğitim Dergisi. Temmuz Dönemi, say1 29. 
Bandura, A., Barbaranelli, C., Caprara, G. ve Pastorelli, C., (1996). Mechanisms of moral disengagement in the exercise of moral agency, Journal of Personality and Social Psychology, 71 (2); 364-374.

Bandura, A., (1999). Moral disengagement in the perpetration of inhumanities, Personality and social psychology review, 3 (3); 193-209.

Bandura, A. (2014). Social cognitive theory of moral thought and action, In: Handbook of moral behavior and development, Eds: Psychology Press. 2014.

Bank, B. J. (2003). Contradictions in women's education: Traditionalism, careerism, and community at a single-sex college, Teachers College Press. 2003.

Baron, R. M. ve Kenny, D. A., (1986). The moderator-mediator variable distinction in social psychological research: Conceptual, strategic, and statistical considerations, Journal of personality and social psychology, 51 (6); 1173.

Barsky, A., (2008). Understanding the Ethical Cost of Organizational Goal-Setting: A Review and Theory Development, Journal of Business Ethics, 81 (1); 63-81.

Batıgün, A. D. ve Şahin, N. H., (2006). İş stresi ve sağlık psikolojisi araştırmaları için iki ölçek: A-tipi kişilik ve iş doyumu, Türk Psikiyatri Dergisi, 17 (1); 32-45.

Bayrakçı, M., (2007). Sosyal ögrenme kuramı ve eğitimde uygulanması, SAÜ Eğ̈itim Fakültesi Dergisi, 14 (10); 198-210.

Bentler, P. M. ve Bonett, D. G., (1980). Significance tests and goodness of fit in the analysis of covariance structures, Psychological bulletin, 88 (3); 588.

Bratton, V. K. ve Kacmar, K. M., (2004). Extreme careerism: The dark side of impression management, The dark side of organizational behavior; 291-308.

Browne, M. W. ve Cudeck, R., (1993). Alternative ways of assessing model fit. Sage focus editions, 154, 136136.

Bülbül, H. ve Demirer, Ö., (2008). Hizmet Kalitesi Ölçüm Modelleri Servqual ve Serperf'in Karşılaştırmalı Analizi, Selçuk Üniversitesi Sosyal Bilimler Enstitüsü Dergisi (20); 181-198.

Chay, Y. W. ve Aryee, S., (1999). Potential moderating influence of career growth opportunities on careerist orientation and work attitudes: Evidence of the protean career era in Singapore, Journal of Organizational Behavior, $20(5) ; 613-623$.

Chen, A., Treviño, L. K. ve Humphrey, S. E., (2020). Ethical champions, emotions, framing, and team ethical decision making, Journal of Applied Psychology, 105 (3); 245.

Christian, J. S. ve Ellis, A. P., (2014). The crucial role of turnover intentions in transforming moral disengagement into deviant behavior at work, Journal of Business Ethics, 119 (2); 193-208.

Churchill Jr, G. A., (1979). A paradigm for developing better measures of marketing constructs, Journal of marketing research, 16 (1); 64-73.

Claybourn, M., (2011). Relationships between moral disengagement, work characteristics and workplace harassment, Journal of Business Ethics, 100 (2); 283-301.

Crust, L., (2020). Personality and mountaineering: A critical review and directions for future research, Personality and individual differences, 163; 110073.

DeCenzo, David. A., Robbins, Stephan P. ve Verhulst, Susan. L. (2017). İnsan Kaynakları Yönetiminin Temelleri, Çev. Ed.: Canan Çetin ve M. Lütfi Arslan, Nobel, Ankara.

Depner, C. E. ve O'Leary, V. E., (1976). Understanding female careerism, Sex Roles, 2 (3); 259-268.

Detert, J. R., Treviño, L. K. ve Sweitzer, V. L., (2008). Moral disengagement in ethical decision making: a study of antecedents and outcomes, Journal of Applied Psychology, 93 (2); 374.

Dijksterhuis, A. ve Aarts, H., (2010). Goals, attention, and (un) consciousness, Annual review of psychology, 61; 467-490.

Doğan, T., (2012). Beş faktör kişilik özellikleri ve öznel iyi olus, Doğuş Üniversitesi Dergisi, 14 (1); $56-64$.

Durna, U., (2005). A tipi ve B tipi kişilik yapilari ve bu kişilik yapilarini etkileyen faktörlerle ilgili bir araştırma, Atatürk Üniversitesi İktisadi ve İdari Bilimler Dergisi, 19 (1); 275-290.

Erbaş, E. ve Perçin, N. Ş., (2017). Ahlaki Çözülme (Moral Disengagement) Ölçeği Türkçe Geçerlemesi ve Kişi-Çevre Uyumu İlişkisi, Bolu Abant İz̨et Baysal Üniversitesi Sosyal Bilimler Enstitüsü Dergisi, 17 (1); 177 190. 
Ettekal, I. ve Ladd, G. W., (2020). Development of aggressive-victims from childhood through adolescence: Associations with emotion dysregulation, withdrawn behaviors, moral disengagement, peer rejection, and friendships, Development and psychopathology, 32 (1); 271-291.

Feldman, D. C. ve Weitz, B. A., (1991). From the invisible hand to the gladhand: Understanding a careerist orientation to work, Human Resource Management, 30 (2); 237-257.

Ficarrotta, J. C., (1988). Careerism: a moral analysis of its nature, types, and contributing causes in the military services, Retrieved, 14.

Fornell, C ve Larcker, D F. (1981). Structural equation models with unobservable variables and measurement error: Algebra and statistics, SAGE Publications Sage CA: Los Angeles, CA. 1981

Freedman, J. L., Sears, D. O. ve Carlsmith, J. M. (1993). Sosyal Psikoloji (Çev: A. Dönmez), Ankara: İmge Kitabevi.

Friedman, M. ve Rosenman, R. H., (1971). Type A Behavior Pattern: its association with coronary heart disease, Ann Clin Res, 3 (6); 300-312.

Friedman, Meyer ve Rosenman, R. H. (1974). Type A behavior and your heart. Fawcett.

Gini, G., Thornberg, R. ve Pozzoli, T., (2020). Individual moral disengagement and bystander behavior in bullying: The role of moral distress and collective moral disengagement, Psychology of violence, 10 (1); 38.

Gökdeniz, İ. ve Merdan, E., (2011). Kişilik ile kariyer seçimi arasındaki ilişkinin incelenmesi, Aksaray Üniversitesi İktisadi İdari Bilimler Fakülte Dergisi. 3(2), 23-36.

Griffin, Ricky W., O'Leary-Kelly, Anne ve Pritchard, Robert D. (2004). The dark side of organizational behavior, Jossey-Bass San Francisco, CA.

Gülmez, Ç. ve Öner, Ü., (2016). Doğal Cevreye Karşı Etik Olmayan Davranıslar Üz̧erinde Ablaki Çözülmenin Etkisi, 3rd International Symposium on Environment and Morality (ISEM2016) 4-6 Nov 2016 Alanya/Antalya-Turkey.

Güney, Salih (2004). Açıklamalı Yönetim-Organizasyon ve Örgütsel Davranış Terimler Sözlüğü. Ankara: Siyasal Kitabevi.

Hatipoğlu, Z., ve Akduman, G. (2019). Psikolojik Sözlesme Iblalinin Örgütsel Sessizlik Üzerindeki Etkisinde Kisilik Özelliklerinin Araci Rolü. Electronic Journal of Social Sciences, 18(72).

Hauser, W. L., (1984). Careerism vs. Professionalism in the Military, Armed Forces \& Society, 10 (3); 449 463.

Hu, L. t. ve Bentler, P. M., (1999). Cutoff criteria for fit indexes in covariance structure analysis: Conventional criteria versus new alternatives, Structural equation modeling: a multidisciplinary journal, 6 (1); 1-55.

Hyde, L. W., Shaw, D. S. ve Moilanen, K. L., (2010). Developmental precursors of moral disengagement and the role of moral disengagement in the development of antisocial behavior, Journal of abnormal child psychology, 38 (2); 197-209.

İnanç, B.Y. ve Yerlikaya, E. E.(2017). Kişilik kuramları, Pegem Atıf İndeksi; 1-339.

İrmiş, A. ve Bayrak, S., (2001). Insan kaynaklar yönetimi açsından kariyer yönetimi, SÜ İ̈BF Sosyal ve Ekonomik Araştırmalar Dergisi. Sayı:1-2, 177-186.

Johnson, J. F. ve Buckley, M. R., (2015). Multi-level organizational moral disengagement: Directions for future investigation, Journal of Business Ethics, 130 (2); 291-300.

Jung, C., (1999). Personality and stress: traits, types, and biotypes, Stress and Health, Third Edition, PL Rice (Ed); 95-126.

Kirkcaldy, B. D., Shephard, R. J. ve Furnham, A. F., (2002). The influence of type A behaviour and locus of control upon job satisfaction and occupational health, Personality and individual differences, 33 (8); 1361-1371.

Kline, P. (2014). An easy guide to factor analysis, Routledge.

Kojima, M., Nagaya, T., Takahashi, H., Kawai, M. ve Tokudome, S., (2004). A chronological decrease in type A behavior patterns among Japanese male workers in 1995-1999, J Occup Health, 46 (2); 171-174.

Larkin, Kevin T. ve Chantler, Paul D. (2020). Stress, depression, and cardiovascular disease, In: Cardiovascular Implications of Stress and Depression, Eds: Elsevier, p. 1-12.

Lefcourt, H. M. (1991). Locus of control, Academic Press.

Lelord, F. ve Andre, C. (1996). Zor Kişilikler le Yaşamak (Çev. R Madenci), İstanbul: İletişim Yayınları. 1996. 
Lewin, A. Y., Sakano, T., Stephens, C. U. ve Victor, B., (1995). Corporate citizenship in Japan: Survey results from Japanese firms, Journal of Business Ethics, 14 (2); 83-101.

Liman, A., Elçi, M. ve Murat, G., (2019). Örgütsel Performansın Öncülleri Olarak Etik Liderlik ve Kariyerizm Üzerine Bir Araştırma, Uluslararası Ekonomi İsletme ve Politika Dergisi, 3 (2); 183-198.

MacKinnon, D. P., Fairchild, A. J. ve Fritz, M. S., (2007). Mediation analysis, Annu. Rev. Psychol., 58; 593-614.

Marsh, H. W. ve Hocevar, D., (1985). Application of confirmatory factor analysis to the study of self-concept: Firstand higher order factor models and their invariance across groups, Psychological bulletin, 97 (3); 562.

Marten, W. D. ve Wilkerson, B., (2003). Stress, work and mental health: a global perspective, Acta neuropsychiatrica, 15 (1); 44-53.

McCrae, R. R. ve Costa Jr, P. T., (1989). Reinterpreting the Myers-Briggs type indicator from the perspective of the five-factor model of personality, Journal of personality, 57 (1); 17-40.

McDonald, R. P. ve Marsh, H. W., (1990). Choosing a multivariate model: Noncentrality and goodness of fit, Psychological bulletin, 107 (2); 247.

Moore, C., Detert, J. R., Klebe Treviño, L., Baker, V. L. ve Mayer, D. M., (2012). Why employees do bad things: Moral disengagement and unethical organizational behavior, Personnel Psychology, 65 (1); 1-48.

Moore, C., (2015). Moral disengagement, Current Opinion in Psychology, 6; 199-204.

Moorhead, G. ve Griffin, R. W. (1992). Organizational Behaviour, 3. B Houghton Mifflin Company, Boston.

Mori, C., Cooke, J. E., Temple, J. R., Ly, A., Lu, Y., Anderson, N., Rash, C. ve Madigan, S., (2020). The prevalence of sexting behaviors among emerging adults: A meta-analysis, Archives of Sexual Behavior; 1-17.

Nusantara, B. A., Sugiharto, D. Y. P. ve Mulawarman, M., (2020). The Effects of The Effects of Empathy on Cyberbullying Mediated by Moral Disengagement on Cyberbullying Mediated by Moral Disengagement, Jurnal Bimbingan Konseling, 9 (2); 116-122.

O'Leary, V. E. ve Braun, J. S., (1972). Antecedents and personality correlates of academic careerism in women, Proceedings of the Annual Convention of the American Psychological Association.

Perren, S. ve Gutzwiller-Helfenfinger, E., (2012). Cyberbullying and traditional bullying in adolescence: Differential roles of moral disengagement, moral emotions, and moral values, European Journal of Developmental Psychology, 9 (2); 195-209.

Polatc1, S., Sobac1, F. ve Kaban, İ., (2020). Kişilike Özellikleri ve Kişi Iss Uyumunun Iss Tatmini Üzerine Etkileri Taşeron Çalssanlar Üzerine Bir Araştırma, Journal of Organizational Behavior Review, 2 (1); 12-30.

Rotter, J. B., (1966). Generalized expectancies for internal versus external control of reinforcement, Psychological monographs: General and applied, 80 (1); 1.

Rotter, J. B., Chance, J. E., \& Phares, E. J. (1972). Applications of a social learning theory of personality. Holt, Rinehart \& Winston.

Saidon, I. M. ve Ab Ghani, N., (2020). How Does Organizational Ethical Climate Affect Interpersonal Deviance? The Role of Moral Disengagement, In: Ethics, Governance and Risk Management in Organizations, Eds: Springer, p. 3-20.

Schilpzand, P., De Pater, I. E. ve Erez, A., (2016). Workplace incivility: A review of the literature and agenda for future research, Journal of Organizational Behavior, 37; S57-S88.

Seriki, O. K., Nath, P., Ingene, C. A. ve Evans, K. R., (2020). How complexity impacts salesperson counterproductive behavior: The mediating role of moral disengagement, Journal of Business Research, 107; 324-335.

Shaw, K.-H., Tang, N. ve Liao, H.-Y., (2020). Authoritarian-Benevolent Leadership, Moral Disengagement, and Follower Unetbical Pro-organizational Behavior: An Investigation of the Effects of Ambidextrous Leadership, Frontiers in Psychology, 11; 590.

Sjögren, B., Thornberg, R., Wänström, L. ve Gini, G., (2020). Bystander behaviour in peer victimisation: moral disengagement, defender self-efficacy and student-teacher relationship quality, Research Papers in Education; 1-23.

Şahin, B., (2016). Kamu Personel Sisteminde İse Girme Ve Yükselmede Çağdaş Liyakat Kavramlar, Çukurova Üniversitesi Sosyal Bilimler Enstitüsü Dergisi, 25 (1); 231-242.

Şahin, N. H., Güler, M. ve Basım, H. N., (2009). A tipi kişilik örüntüsünde bilisssel ve duygusal zelkânn stresle başa ģıkma ve stres belirtileri ile iliskkisi, Türk Psikiyatri Dergisi, 20 (3); 243-254. 
Tanaka, J. S. ve Huba, G. J., (1985). A fit index for covariance structure models under arbitrary GLS estimation, British Journal of Mathematical and Statistical Psychology, 38 (2); 197-201.

Townsend, B. K., (2005). Contradictions in Women's Education: Traditionalism, Careerism, and Community at a Single-Sex College, The Review of Higher Education, 28 (3); 451-452.

Üzüm, B., (2018). Kariyerizm Bir Davranış Eğilimi Olarak Negatif midir? Pozitif midir?, Social Sciences Studies Journal, 4; 5351-5354.

Wang, X., Yang, J., Wang, P., Zhang, Y., Li, B., Xie, X. ve Lei, L., (2020). Deviant peer affiliation and bullying perpetration in adolescents: the mediating role of moral disengagement and the moderating role of moral identity, The Journal of Psychology, 154 (3); 199-213.

Yang, Y., Guo, Z., Wu, J. ve Kou, Y., (2020). Self-Compassion Relates to Reduced Unethical Behavior Through Lower Moral Disengagement, Mindfulness; $1-9$.

Yıldırım, A., (1999). Nitel araştırma yöntemlerinin temel özellikleri ve eğitim araştırmalarndaki yeri ve önemi, Eğitim ve Bilim, 23 (112).

Y1ldiz, B. (2015). The Antecedents of Constructive and Destructive Deviant Workplace Behaviors. Unpublished Doctoral Dissertafion, Kocaeli: Gebze Technical University.

Yildiz, B. ve Alpkan, L., (2015). A theoretical model on the proposed predictors of destructive deviant workplace behaviors and the mediator role of alienation, Procedia-Social and Behavioral Sciences, 210; 330-338.

Y1ldı, B., Alpkan, L., Sezen, B. ve Y1ldı, H., (2015a). A proposed conceptual model of destructive deviance: The mediator role of moral disengagement, Procedia-Social and Behavioral Sciences, 207; 414-423.

Yıldız, B., Yıldız, H. ve Alpkan, L., (2015b). Olağandışı İsyeri Davranıslarını Bir Öncülü Olarak Kariyerižm. 3. Örgütsel Davranış Kongresi, Tokat, Türkiye, s. 684-689.

Y1ldı, B. ve Arda, Ö. A., (2018). İy bir asker mi? İyi bir illüzyonist mi? Kariyerizm ile zorunlu vatandaşlı davranışlar arasındaki ilişkide işten ayrlma niyetinin rolü, Business and Economics Research Journal, 9 (1); 151 168. 